\title{
CHEMICAL COMPOSITION OF THE ESSENTIAL OIL FROM THE SEEDS OF THE MEDICINAL PLANT MENTHA LONGIFOLIA (L.) HUDS.
}

\author{
MINA BAKHSHESHI ${ }^{1,3}$, JINOUS ASGARPANAH $^{2,3 *}$ \\ ${ }^{I}$ Department of Phytochemistry and Essential Oil Technology, Faculty of Pharmaceutical Chemistry, Pharmaceutical Sciences \\ Branch, Islamic Azad University (IAUPS), Tehran, Iran \\ ${ }^{2}$ Department of Pharmacognosy, Faculty of Pharmacy, Pharmaceutical Sciences Branch, Islamic Azad University (IAUPS), \\ Tehran, Iran \\ ${ }^{3}$ Herbal Medicines Research Center (HMRC), Pharmaceutical Sciences Branch, Islamic Azad University, Tehran, Iran
}

*corresponding author: taxolfa@yahoo.com

Manuscript received: July 2016

\begin{abstract}
The essential oil from the seeds of Mentha longifolia (L.) Huds. growing wild in Iran was isolated by hydrodistillation and analysed by gas-chromatography coupled with mass spectrometry (GC-MS). The main components in seeds were piperitenone (40.9\%) and piperitone (29.4\%).
\end{abstract}

\section{Rezumat}

Uleiul volatil obţinut din seminţe uscate de Mentha longofolia (L.) Huds. Din flora spontană a Iranului, a fost izolat prin hidrodistilare şi analizat prin cromatografie de gaze cuplată cu spectrometrie de masă (GC-MS). Principalii componenţi regăsiți în semințe au fost piperitenona (40,9\%) şi piperitona $(29,4 \%)$.

Keywords: Mentha longifolia, Lamiaceae, seed, essential oil

\section{Introduction}

The native plant Mentha longifolia (L.) Huds. belongs to the Lamiaceae family and is known locally as "Pooneh" [1]. It widely grows in Asia, Eurasia, Australia, and South and North Africa [2] and in various regions of Iran. The aerial parts of $M$. longifolia have a strong aroma and are commonly used as an aromatic and medicinal plant. It has a great role in medicine including the Iranian traditional medicine as a stomach pain-relieving agent, antispasmodic, digestive and carminative [3]. Literature survey revealed several reports just on the essential oil composition of the leaves and the aerial parts of $M$. longifolia [4-6] and there was no attempt to study the essential components of the seeds up to now. Considering the significant pleasant odour of the seeds, we were prompted to investigate the essential oil composition of $M$. longifolia seeds for the first time.

\section{Materials and Methods}

Plant material

Fresh seeds of $M$. longifolia were collected in June 2015 from Meymand village, Fareghan, Hadji-Abad County, Hormozgan Province, Iran $\left(28^{\circ} 18^{\prime} 33^{\prime \prime} \mathrm{N}\right.$ $55^{\circ} 54^{\prime} 06^{\prime \prime} \mathrm{E}, 1500 \mathrm{~m}$ ). The specimen was identified by R. Asadpour and a voucher was deposited in the Herbarium of Pharmaceutical Sciences Branch, Islamic
Azad University (IAUPS), Tehran, Iran, under the code number 306-PMP/A. Seeds were powdered and submitted to hydrodistillation in a Clevenger-type apparatus for 3 hours. At the end of distillation, the oil was collected, dried with anhydrous $\mathrm{Na}_{2} \mathrm{SO}_{4}$, measured, and transferred to a clean glass vial and kept at a temperature of $-18^{\circ} \mathrm{C}$ for further analyses.

Analysis of the essential oil

Oil sample analysis was performed on a HP-6890 gas chromatograph (GC) equipped with a FID and a DB-5 capillary column, $30 \mathrm{~m} \times 0.25 \mathrm{~mm}, 0.25 \mu \mathrm{m}$ film thickness, temperature programmed as follows: $60^{\circ} \mathrm{C}-240^{\circ} \mathrm{C}$ at $4^{\circ} \mathrm{C} / \mathrm{min}$. The carrier gas was $\mathrm{N}_{2}$ at a flow rate of $2.0 \mathrm{~mL} / \mathrm{min}$; injector port and detector temperature were $250^{\circ} \mathrm{C}$ and $300^{\circ} \mathrm{C}$, respectively. The sample was injected by splitting and the split ratio was $1: 10$.

GC/MS analysis was performed on a Hewlett-Packard $6890 / 5972$ system with a DB-5 capillary column (30 $\mathrm{m} \times 0.25 \mathrm{~mm} ; 0.25 \mu \mathrm{m}$ film thickness). The operating conditions were the same conditions as described above but the carrier gas was He. Mass spectra were recorded at $70 \mathrm{eV}$. Scan mass range was from $40-400 \mathrm{~m} / \mathrm{z}$ at a sampling rate of $1.0 \mathrm{scan} / \mathrm{s}$. Quantitative data were obtained from the electronic integration of the FID peak areas. The components of the oil were identified by their retention time, retention indices, relative to $\mathrm{C}_{9}-\mathrm{C}_{28}$ n-alkanes, computer matching with the WILEY275.L library and 
as well as by comparison of their mass spectra with data already available in the literature [7, 8]. The relative content of the identified components were calculated from the GC peaks areas. The analysis of the essential oil is presented as the average of three replicates.

\section{Results and Discussion}

The hydrodistillation of $M$. longifolia seeds resulted in a pale yellow oil with pleasant odour and yield of $4.0 \%$ $(\mathrm{v} / \mathrm{w})$ based on the fresh weight. Figure 1 shows the gas chromatogram of $M$. longifolia seed essential oil. Table I presents the list of compounds with a concentration over $0.1 \%$ of the total peak concentration. According to Table I, eighteen components were identified in the seeds essential oil which represented about $95.5 \%$ of the total composition. The major constituents of $M$. longifolia seed oil were characterized as piperitenone (40.9\%) and piperitone (29.4\%). The studied essential oil comprised fourteen monoterpenoids $(92.9 \%)$ and four sesquiterpenoids $(2.6 \%)$.

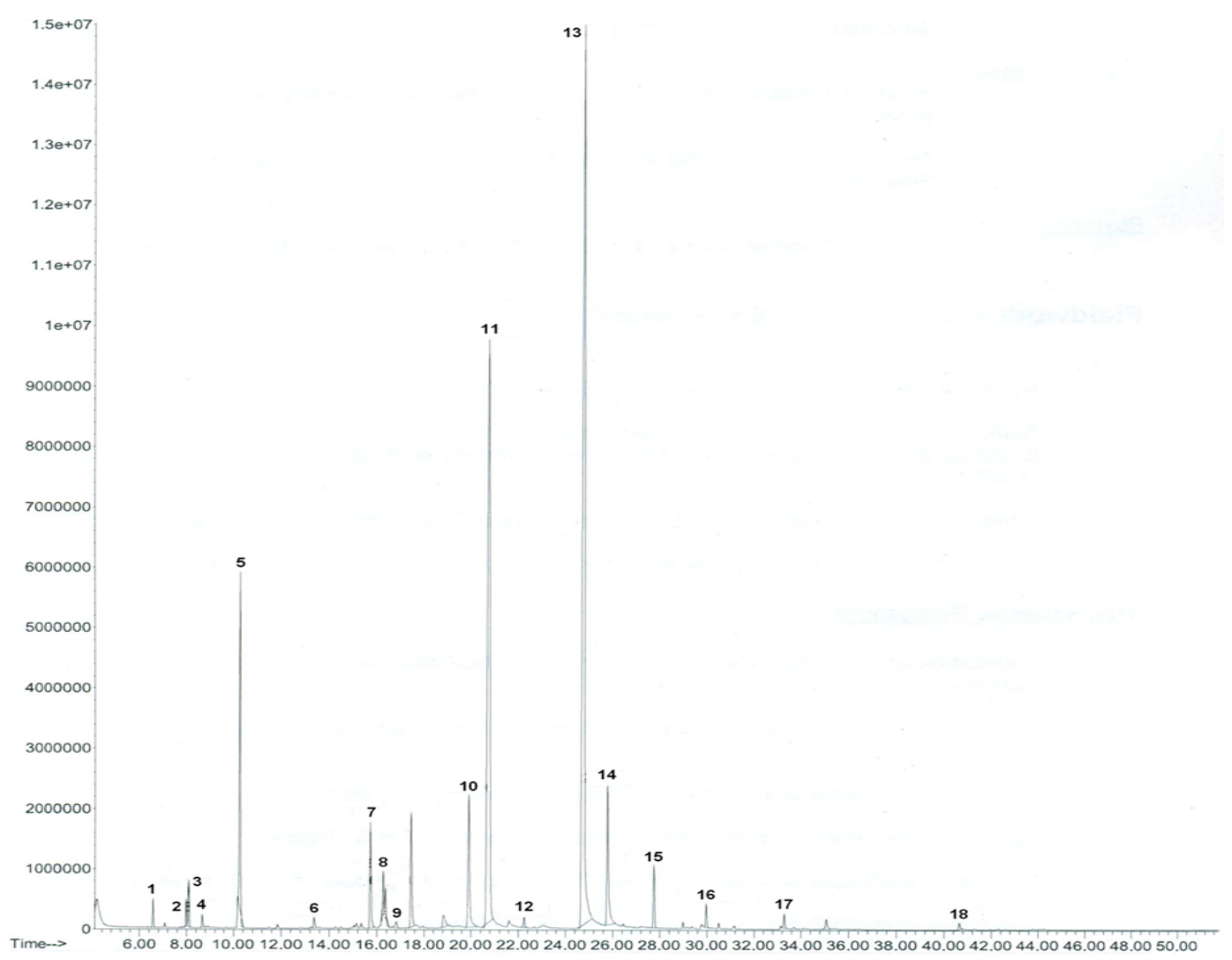

Figure 1.

The gas chromatogram of M. longifolia seeds essential oil

Table I

GC-MS analysis of M. longifolia seeds essential oil

\begin{tabular}{lccc}
\hline \multicolumn{1}{c}{ Compound $^{\mathrm{a}}$} & $\mathrm{KI}^{\mathrm{b}}$ & $\mathrm{KI}^{\mathrm{c}}$ & Percentage \\
\hline 1. $\alpha$-Pinene & 942 & 939 & 0.5 \\
2. Sabinene & 972 & 975 & 0.4 \\
3. $\beta$-Pinene & 976 & 979 & 0.9 \\
4. $\beta$-Myrcene & 996 & 991 & 0.3 \\
5. 1,8-Cineol & 1028 & 1031 & 6.8 \\
6. Linalool & 1101 & 1097 & 0.3 \\
7. Menthone & 1149 & 1153 & 2.7 \\
8. Borneol & 1166 & 1169 & 1.0 \\
9. Terpinene-4-ol & 1179 & 1177 & 0.2 \\
10. Pulegone & 1241 & 1237 & 4.6 \\
11. Piperitone & 1255 & 1253 & 29.4
\end{tabular}


FARMACIA, 2018, Vol. 66, 6

\begin{tabular}{lccc}
\hline \multicolumn{1}{c}{ Compound } & $\mathrm{KI}^{\mathrm{b}}$ & $\mathrm{KI}^{\mathrm{c}}$ & Percentage \\
\hline 12. Bornyl acetate & 1287 & 1289 & 0.3 \\
13. Piperitenone & 1339 & 1343 & 40.9 \\
14. Piperitenone oxide & 1372 & 1369 & 4.6 \\
15. trans-Caryophyllene & 1418 & 1419 & 1.5 \\
16. Germacrene D & 1489 & 1485 & 0.5 \\
17. Caryophyllene oxide & 1579 & 1583 & 0.4 \\
18. 6,10,14-trimethyl-2-pentadecanone & 1843 & 1840 & 0.2 \\
\hline Total & & & 95.5 \\
\hline
\end{tabular}

${ }^{\mathrm{a} C}$ Compounds listed in the order of elution. ${ }^{\mathrm{b}} \mathrm{KI}$ (Kovats index) measured relative to $n$-alkanes $\left(\mathrm{C}_{9}-\mathrm{C}_{28}\right)$ on the non-polar DB-5 column. ${ }^{\mathrm{c}} \mathrm{KI}$, (Kovats index) from literature.

Piperitenone as the major component of the studied oil is a monoterpene ketone and is found to be one of the main metabolites of the potent hepatotoxin, pulegone [9]. The presence of a high amount of piperitenone compared to the low content of pulegone $(4.6 \%)$ in M. longofolia seed oil is considerable and demonstrates a characteristic metabolic pathway in

the seed cells in which piperitenone could highly be metabolized from pulegone.

Six reports on the analysis of $M$. longofolia aerial part oils collected from different parts of Iran have been published [4-6]. A comparison of the results with the literature showed differences between $M$. longofolia seed oil and that of M. longofolia aerial parts collected at full flowering stage.

Table II

Essential oil main components of the aerial parts of six M. longifolia collected at full flowering stage from different regions in Iran comparing with those of the seed oil (>5\%)

\begin{tabular}{lccccccc}
\hline \multicolumn{1}{c}{ Compound } & M. longifolia seed & A & B & C & D & E & F \\
\hline Piperitenone & 40.9 & 43.9 & - & - & - & - & - \\
Piperitone & 29.4 & - & - & - & - & - & - \\
1,8-Cineol & 6.8 & - & - & 14.3 & 13.4 & 7.7 & 7.3 \\
Tripal & - & 14.3 & - & - & - & - & - \\
Oxathiane & - & 9.3 & - & - & - & - & - \\
Piperitenone oxide & - & 5.9 & - & - & 59.7 & 38.0 & 54.2 \\
Carvone & - & - & 72.3 & 62.3 & - & - & - \\
Limonene & - & - & 19.3 & - & - & - & - \\
Pulegone & - & - & - & - & 7.6 & 31.1 & - \\
$\alpha$-Terpineol & - & - & - & - & - & 6.0 & - \\
\hline
\end{tabular}

$\mathrm{A}=\bar{M}$. longifolia aerial parts collected from Sarayan, South Khorasan Province, Southeast of Iran [4]; B $=$ M. longifolia aerial parts collected from Ghazvin Province, North of Iran [5]; C = M. longifolia aerial parts collected from Ardebil Province, Northwest of Iran [5]; D = M. longifolia aerial parts collected from Shahrekord, West of Iran [6]; E = M. longifolia aerial parts collected from Isfahan Province, Central of Iran [6]; F = M. longifolia aerial parts collected from Yasuj, West of Iran [6].

Table II shows the main compounds of M. longofolia seed oil and those of six other M. longofolia aerial parts. The presence of piperitenone, the major component in the seed oil, in the aerial parts of M. longofolia oil collected from the Southeast of Iran with nearly the same amounts is characteristic. Piperitenone oxide has been reported as the main component of the oils in the aerial parts of three studied species collected from the West and central parts of Iran. This component exists in the seed oil in very low amounts. The oil of M. longofolia collected from North of Iran is completely different from that of the seeds and the absence of all three seed oil major components in it is noticeable. Plant organ and vegetative cycle stage are the main reasons for differences in $M$. longofolia aerial parts and seeds essential oil compositions.

\section{Conclusions}

This paper presents the essential oil composition of M. longifolia seeds for the first time. Due to the presence of piperitenone and piperitone as the major components of the seeds oil, future studies on the biological and pharmacological properties of the oil are suggested.

\section{Acknowledgement}

Supports from the Pharmaceutical Sciences Branch, Islamic Azad University (IAUPS) are gratefully acknowledged.

\section{References}

1. Mozaffarian V, A Dictionary of Iranian Plants Name. Farhang Moaser Press, Tehran, Iran, 2006.

2. Sharopov FS, Sulaimonova VA, Setzer WN, Essential oil composition of Mentha longifolia from wild populations growing in Tajikistan. $J$ Med Active Plns., 2012; 1: 76-84.

3. Zargari A, Medicinal Plants, Tehran, Iran: Tehran University Publ., Tehran, Iran, 1990.

4. Khani A, Asghari J, Insecticide activity of essential oils of Mentha longifolia, Pulicaria gnaphalodes and Achillea wilhelmsii against two stored product pests, the flour beetle, Tribolium castaneum, and the 
FARMACIA, 2018, Vol. 66, 6

cowpea weevil, Callosobruchus maculatus. J Insect Sci., 2012; 12: 73-78.

5. Abbaszadeh B, Teymoori M, Pouyanfar M, Rezaei MB, Mafakheri S, Growth and essential oil of Mentha longifolia $\mathrm{L}$. (var. amphilema) from different ecological conditions. Annal Biol Res., 2013; 4: 85-90.

6. Saeidi Z, Babaahmadi H, Saeidi KA, Salehi A, Saleh Jouneghani R, Amirshekari H, Taghipour A, Essential oil content and composition of Mentha longifolia (L.) Hudson grown wild in Iran. $J$ Med Pln Res., 2012; 6: 4522-4525.
7. Swigar AA, Silverstein RM, Monoterpenes. WI: Aldrich Chemical Company Publ., Milwaukee, USA, 1981.

8. Adams RP, Identification of Essential Oil Components by Gas Chromatography/Mass Spectroscopy. Allured Publishing Co., Carol Stream, IL, 2007.

9. Madyastha KM, Gaikwad NW, Metabolic disposition of a monoterpene ketone, piperitenone, in rats: evidence for the formation of a known toxin, p-cresol. Drug Metab Dispos., 1999; 27: 74-80. 